\title{
Correction to: The effect of self-limiting on the prevention and control of the diffuse COVID-19 epidemic with delayed and temporal-spatial heterogeneous
}

Cheng-Cheng Zhu ${ }^{1}$ and Jiang Zhu ${ }^{2^{*}}$

\section{Correction to: BMC Infect Dis (2021) 21:1145} https://doi.org/10.1186/s12879-021-06670-y

Following publication of the original article [1], an error was identified in page 11.

The font of the first and fifth lines currently read: $\mathrm{L}$

The font should read: $\mathcal{L}$.

Furthermore an error was identified in formula (7).

The formula currently read: $\mu(x, t) A$.

The formula should read $\Lambda(x, t)$.

The original article [1] has been corrected.

\section{Reference}

1. Zhu C-C, Zhu J. The effect of self-limiting on the prevention and control of the diffuse COVID-19 epidemic with delayed and temporal-spatial heterogeneous. BMC Infect Dis. 2021;21:1145. https://doi.org/10.1186/ s12879-021-06670-y.

\section{Publisher's Note}

Springer Nature remains neutral with regard to jurisdictional claims in published maps and institutional affiliations.

Author details

${ }^{1}$ School of Science, Jiangnan University, Wuxi 214122, China. ${ }^{2}$ School of Mathematics and Statistics, Jiangsu Normal University, Xuzhou 221116, China.

Published online: 05 January 2022

@ The Author(s) 2021. Open Access This article is licensed under a Creative Commons Attribution 4.0 International License, which permits use, sharing, adaptation, distribution and reproduction in any medium or format, as long as you give appropriate credit to the original author(s) and the source, provide a link to the Creative Commons licence, and indicate if changes were made. The images or other third party material in this article are included in the article's Creative Commons licence, unless indicated otherwise in a credit line to the material. If material is not included in the article's Creative Commons licence and your intended use is not permitted by statutory regulation or exceeds the permitted use, you will need to obtain permission directly from the copyright holder. To view a copy of this licence, visit http://creativecommons.org/licenses/by/4.0/. The Creative Commons Public Domain Dedication waiver (http://creativeco mmons.org/publicdomain/zero/1.0/) applies to the data made available in this article, unless otherwise stated in a credit line to the data. 